\title{
Structural Change in U.S. Wage Determination
}

\author{
Robert W. Rich \\ Donald Rissmiller
}

March 5, 2001

We would like to thank Arturo Estrella, Erica Groshen, Jim Kahn, Simon Potter, Tony Rodrigues, Kevin Stiroh and Joe Tracy for helpful comments and suggestions. We are also grateful to Bruce Hansen as well as to Arturo Estrella and Tony Rodrigues for assistance with programs used in performing the computations. The views expressed in this paper are those of the authors and do not necessarily reflect the position of the Federal Reserve Bank of New York or the Federal Reserve System. The authors are solely responsible for any remaining errors. 


\title{
Structural Change in U.S. Wage Determination \\ by
}

Robert W. Rich and Donald Rissmiller

\begin{abstract}
This paper provides an empirical investigation into the determinants and stability of the aggregate wage inflation process in the United States over the period 1967-2000. Using compensation per hour as the measure of wages, we specify a Phillips curve model that links wage growth to its past values as well as to the unemployment rate, price inflation, labor productivity growth and an additional set of labor market variables. The results do not reject the hypothesis that real wages and labor productivity move proportionally in the long-run. More importantly, endogenous structural break tests provide little evidence of model instability. We conclude that aggregate wage determination has remained stable over the last thirty years and that any recent shift in the inflation-unemployment relationship reflects developments outside the labor market.
\end{abstract}

Robert W. Rich

Federal Reserve Bank of New York

33 Liberty Street

New York, NY 10045-0001

Robert.Rich@ny.frb.org

(212) 720-8100 [Phone]

(212) 720-1844 [FAX]
Donald Rismiller

Federal Reserve Bank of New York

33 Liberty Street

New York, NY 10045-0001

Donald.Rissmiller@ny.frb.org

(212) 720-8090 [Phone]

(212) 720-1844 [FAX] 
The U.S. economy has performed remarkably well over the last decade. The current expansion, which started in April 1991, is the longest in the post-war period. In addition to its surprising longevity, this boom has been characterized by the unusual coincidence of declining unemployment and declining price inflation. While there is a consensus that the combination of sustained growth, low unemployment and falling inflation is an impressive economic accomplishment, there has been considerable debate over the factor(s) responsible for the confluence of these favorable occurrences.

Some commentators claim that the recent coexistence of low unemployment and low price inflation -- the so-called "inflation puzzle" -- is a consequence of changes in the labor market. Gordon (1997) constructs time-varying estimates of the non-accelerating inflation rate of unemployment (NAIRU) and reports a marked and steady decline in its value during the 1990s. Katz and Krueger (1999) cite evidence of restraint in wage growth since 1988 and argue that this development is primarily due to demographic shifts and the rise of labor market intermediaries. Akerlof, Dickens and Perry (2000) appeal to the concept of near-rational behavior and the idea that agents/firms may entirely ignore inflation or only partially incorporate inflationary expectations into wage (and price) setting decisions in a low inflation environment. While displaying some differences, these studies link recent trends in employment and price inflation to structural change in the labor market and instability in the wage inflation process. ${ }^{1}$

The changing nature of U.S. wage determination has been the focus of previous research. For example, studies have analyzed changes in the relative wage structure [Bound and Johnson (1992), Murphy and Welch (1992)], increased income inequality [DiNardo, Fortin, and Lemieux

${ }^{1}$ Gomme (1998) also provides an investigation into the "New Economy" paradigm and its implications for labor market behavior. 
(1996)], changing wage gaps between demographic groups [Blau and Kahn (1992)] and changes in union wage determination [Mitchell (1994)]. Moreover, interest in the stability of aggregate wage determination did not originate with events transpiring during the current expansion. In particular, several studies [Mitchell (1985, 1987), Gordon (1988), Vroman and Abowd (1988), Neumark (1993), Neumark and Leonard (1993), Budd and Nho (1997)] have examined the behavior of aggregate labor-cost inflation and reported evidence of a breakdown in the early 1980s in estimated Phillips curves.

This paper provides an empirical investigation into the determinants and stability of the aggregate U.S. wage inflation process. In spite of the accumulated evidence and conclusions of previous researchers, we nevertheless believe that there are several reasons why a return to this issue is worthwhile. First, it is our contention that previous Phillips curve specifications may neither adequately capture nor fully describe the dynamics of the wage inflation process. In particular, we emphasize the importance of long lag lengths and coefficient smoothing restrictions for some of the explanatory variables. Second, we also examine the common practice of splicing alternative series to construct the measure of nominal wages and its consequences for the estimation results. Last, we adopt a more formal approach to address the issue of model stability. Specifically, recent advances in the theory and conduct of structural break tests now allow for an endogenous identification of change points and recognize the interdependence of the posited change point and the sampling distribution of the test statistics.

For the analysis, we employ compensation per hour as the measure of nominal wages. We specify a Phillips curve model that links wage growth to its past values as well as to the unemployment rate, price inflation, labor productivity growth and an additional set of labor 
market variables. We estimate the model using quarterly data from 1967:Q1 through 2000:Q2.

The results do not reject the hypothesis that real wages and labor productivity move proportionally in the long-run. More importantly, the results of structural break tests developed by Andrews (1993) and Andrews and Ploberger (1994) provide little evidence of a change in the U.S. wage inflation process and are consistent with the assumption of a constant natural rate of unemployment. While the construct of these structural break tests precludes us from directly addressing the issue of model stability over the last three years, we are persuaded that the sustained coincidence of low unemployment and low inflation during the 1990s does not stem from structural change in the labor market and a decline in wage pressure. ${ }^{2}$

We also extend the analysis and try to provide some insight into the reason(s) why our results typically differ from those of other studies. Drawing upon the existing literature, we explore the consequences of a composite wage measure and short lag lengths for model stability. We find that the use of a spliced wage series can lead to a greater incidence of model instability. In addition, we find that the failure to adopt long lags and coefficient smoothing restrictions on the price inflation and labor productivity growth series can also lead to a greater incidence of model instability. ${ }^{3}$ Thus, we conclude that previous evidence of a breakdown in wage Phillips curves may be more closely linked to issues concerning the construction of the wage measure and model specification than to actual structural change in the labor market.

${ }^{2} \mathrm{~A}$ detailed and extensive investigation into the issue of an "inflation puzzle" is beyond the scope of this paper. Accordingly, we do not examine linkages from wages (or unit labor costs) to prices such as the behavior of markups or other issues related to 'cost-push' inflation.

${ }^{3}$ The smoothing restrictions can also be important for documenting that real wages grow in line with labor productivity in the long-run. 
In the next section of the paper, we review previous investigations into the determinants and stability of the aggregate U.S. wage inflation process. Section 3 describes the model and variables used in the estimation. Section 4 discusses the empirical results and examines how differences in the construct of the wage measure and in model specification can affect the inferences drawn about parameter stability and the validity of theoretical restrictions imposed on the data. We also discuss estimates of the natural rate of unemployment and their precision. Section 5 concludes.

\section{Aggregate Labor-Cost Inflation: A Literature Review}

Much of the early work focusing on changes in aggregate wage determination in the U.S. appears motivated by the weakening of unions in the 1980s. Several studies [Mitchell (1985, 1987), Gordon (1988), Vroman and Abowd (1988)] document a consistent overprediction of wage inflation during the 1980s based on estimated Phillips curve equations. Because the restraint in nominal wage growth coincided with an accelerated decline in union strength, it was thought that the two occurrences might be causally linked. Empirical research, however, has suggested that the decline in union strength in the 1980s explains little if any of the deceleration of labor-cost inflation in the decade [Neumark (1993)].

The unusual coincidence of low inflation and low unemployment during the 1990s has led researchers to focus again on the labor market and the stability of the aggregate wage inflation process. It is important to note that this renewed interest does not imply the absence of alternative explanations for the observed declines in unemployment and price inflation. For example, modern versions of the Phillips curve can account, in principle, for these events by arguing that the decade 
witnessed a sequence of favorable, albeit transitory supply shocks [Gordon (1998), Rich and Rissmiller (2000)]. However, some commentators view this line of argument as unsatisfactory for two reasons. First, this argument does not place primary import on the widely-held belief that the NAIRU has declined during the 1990s. ${ }^{4}$ Second, much debate continues about whether cited transitory factors have the requisite timing and magnitude to fully account for the recent declines in unemployment and price inflation. ${ }^{5}$ Consequently, some researchers have looked for structural labor market changes to account for the experience of the 1990s.

Katz and Krueger (1999) provide an overview of U.S. labor market behavior and note several changes in its features over the past decade. For example, their findings indicate that the wage Phillips curve has displayed a favorable shift since 1988. They also claim that the Beveridge curve has shifted. ${ }^{6}$ In addition, they evaluate several hypotheses concerning the sources of the recent declines in unemployment and wage pressure. The hypotheses include changing demographic trends in the labor force, increased job insecurity, improved efficiency in labor market matching, and the increased degree of incarceration among low-skilled workers. Katz and Krueger conclude that demographic shifts and the rise of labor market intermediaries are the principal sources.

Akerlof, Dickens and Perry (2000) focus their attention on the inflation expectations

${ }^{4}$ It is worth noting that such discussions focusing on the NAIRU involve a high degree of uncertainty associated with the magnitude, persistence, and sources of its decline. For example, Stock, Staiger and Watson (1997) find that NAIRU estimates are very imprecise. Blanchard and Katz (1997) conclude that economists do not have a good quantitative understanding of the determinants of the natural rate of unemployment, either across time or across countries.

${ }^{5}$ See Brayton, Roberts and Williams (1999).

${ }^{6}$ The Beveridge curve relates job vacancies to the unemployment rate. 
formation process. Specifically, they argue that economic agents only behave according to the tenets of the rational expectations hypothesis in a high inflation environment, displaying "nearrational" behavior in a low inflation environment. According to this argument, agents may choose to ignore inflation or only partially incorporate inflationary expectations into their decisionmaking process at low rates of inflation. ${ }^{7}$ Akerlof, Dickens and Perry estimate wage (and price) inflation Phillips curves using post-war U.S. data and cite evidence of parameter instability on the lagged inflation term to support their claim. In particular, they find that the coefficient on lagged inflation is low during periods of low inflation and approaches unity only during the high inflation decade of the 1970s. ${ }^{8}$

Taken together, the body of empirical evidence appears to document instability in the aggregate U.S. wage inflation process over the post-war period. On closer inspection, however, it becomes evident that there are substantial differences across studies with regard to model specification, data and methodology. Consequently, an alternative interpretation of the evidence might suggest that conclusions drawn about structural change in aggregate wage determination are tenuous due to these considerations.

Most empirical studies have used a Phillips curve equation to explain the movements in wage inflation over time. In particular, nominal wage growth typically is assumed to depend on

${ }^{7}$ An implication of this argument is that there is a section of the long-run Phillips curve that is not vertical and instead bows inward at low inflation rates.

${ }^{8}$ Neumark and Leonard (1993) also explore the role of changes in the inflation expectations process on structural shifts in aggregate U.S. wage determination, although they restrict their attention to the period of the 1980s. They argue that the overprediciton of wage inflation based on estimated Phillips curve equations during this period cannot be attributed to deviations between actual and expected price inflation. 
the level of unemployment, lagged price inflation, and a measure of labor productivity growth. While these studies share a common set of explanatory variables, there is little consensus in the construct and treatment of the variables. For example, the unemployment rate is sometimes specified as an aggregate measure [Tootell (1994), Fuhrer (1995), Katz and Krueger (1999)], a demographically-adjusted aggregate variable [Gordon (1988, 1997, 1998), Akerlof, Dickens and Perry (2000), Tulip (2000)], or the value pertaining to a specific demographic group such as prime-age (25-54) males [Neumark and Leonard (1993), Budd and Nho (1997)].

The choice of lag lengths also varies considerably across studies. For example, the inflation rate is specified as a single, lagged quarterly percent change [Budd and Nho (1997)], a year-over-year percent change [Katz and Krueger (1999)], a distributed lag of quarterly percent changes [Tootell (1994), Fuhrer (1995), Akerlof, Dickens and Perry (2000)], or a smoothed distributed lag of quarterly percent changes [Tulip (2000)]. Similarly, labor productivity growth is specified as a constant [Katz and Krueger (1999)], a single, quarterly percentage change [Budd and Nho (1997)], a distributed lag of quarterly percent changes [Tootell (1994)], or a (smoothed) trend measure [Gordon (1988, 1997, 1998), Akerlof, Dickens and Perry (2000), Tulip (2000)]. Empirical investigations into the determinants and stability of the aggregate labor-cost inflation process also require the selection of a measure of wages. Neumark (1993), Neumark and Leonard (1993), Tootell (1994), and Budd and Nho (1997) use compensation per hour (for the U.S. nonfarm business sector). Other studies, however, have employed a composite measure that incorporates data on the employment cost index (ECI) starting in the early 1980s. ${ }^{9}$ For example,

\footnotetext{
${ }^{9} \mathrm{~A}$ time series for the ECI is only available beginning in 1980:Q1 for private industry workers and in 1982:Q1 for civilian workers.
} 
Gordon (1998) and Akerlof, Dickens and Perry (2000) splice data from the average (adjusted) hourly earnings index and the ECI for wages and salaries at 1980, while Fuhrer (1995) and Tulip (2000) splice compensation per hour and the ECI at 1982 and 1980, respectively. ${ }^{10}$

The apparent motivation to construct these composite wage measures is that the ECI not only tracks total compensation [wages (and salaries) and benefits], but also provides separate data series on the two components. Abstracting from a debate over which average wage measure may be best, there is the practical question of how splicing alternative wage series may impact on model estimation and stability. ${ }^{11}$ We will address this issue during the course of our empirical analysis.

A final concern relates to the conduct of tests for parameter instability. While studies have employed a variety of testing procedures, the testing procedures generally have involved the $a$ priori selection of the breakpoint. ${ }^{12}$ As Hansen (1992) notes, this consideration raises a number of problems. First, standard testing theory is not applicable because the date of structural change is not defined under the null hypothesis (of constant parameters). Second, the selection of a breakpoint based on known events can be problematic unless one can argue that the events are selected exogenously. Last, the reliance on visual inspection of the data or regression diagnostics to identify the breakpoint is again problematic due to the nonstandard distribution of the test

\footnotetext{
${ }^{10}$ Gordon (1998) also considers a wage series that splices an "adjusted" compensation measure and the ECI at 1980.

${ }^{11}$ The popularity of the ECI may also be due to its availability at an industry or occupational level. In addition to its short history, other disadvantages of the ECI are that it excludes certain types of payments (stock options, tips, referral bonuses, etc.) and its fixed weights become obsolete over time [Lebow, Sheiner, Slifman and Starr-McCluer (1999)].

${ }^{12}$ One exception is Budd and Nho (1997).
} 
statistic as well as the conditional nature of the selection process. ${ }^{13}$

Recent advances in statistical theory and econometrics now allow for the design and conduct of tests for parameter instability that are robust to these concerns. Among the proposed testing procedures, the structural break tests developed by Andrews (1993) and Andrews and Ploberger (1994) are particularly popular because they allow for an endogenous determination of change points yet are quite tractable. The techniques are also attractive because they can be used to test for the stability of individual parameters, a subset of the parameter vector, or the entire parameter vector. Moreover, Hansen (1997) has proposed approximation methods that allow the asymptotic $p$ values to be calculated for the Andrews (1993) and Andrews and Ploberger (1994) structural break tests. Our analysis will employ these techniques to conduct tests for stability in the aggregate U.S. wage inflation process. ${ }^{14}$

\section{Model Specification and Data}

Our study principally relies on formulating a model of aggregate wage determination and then focusing on the stability of the estimated parameters over the sample period. We start by considering a conventional Phillips curve specification that relates nominal wage growth $(\Delta W)$ to the unemployment rate $(U)$, price inflation $(\Delta P)$, and labor productivity growth $(\Delta \theta)$ :

${ }^{13}$ The CUSUM and CUSUM of squares tests are other popular tests for model instability. While not widely used in the literature on aggregate wage determination in the U.S., these tests are problematic because they display poor power and also amount to a test for a shift in the intercept or variance of a regression model. See Hansen (1992) for further discussion.

${ }^{14}$ Prior to the work of Hansen (1997), researchers only had access to the tabulated asymptotic critical values for the distribution of the Andrews and Andrews/Ploberger test statistics, and therefore were limited to accepting/rejecting the null hypothesis of model stability. 


$$
\Delta W_{t}=a_{0}+b(L) U_{t}+c(L) \Delta P_{t}+d(L) \Delta \theta_{t}+\epsilon_{t}
$$

where $b(L), c(L)$ and $d(L)$ are polynomials in the lag operator $L$ and $\epsilon_{t}$ is a mean-zero, serially uncorrelated random disturbance term. The set of explanatory variables includes the unemployment rate to gauge demand pressure in the labor market, price changes to proxy inflation expectations, and a measure of productivity growth to capture changes in the efficiency of labor input over time. ${ }^{15}$ As with other studies, we do not attempt to ascribe a structural interpretation to equation (1). Rather, we simply view the Phillips curve specification as providing a reasonable and useful empirical description of the dynamics of the aggregate wage inflation process.

Estimation of equation (1) typically proceeds with two restrictions imposed on the data. The first restriction is based on the assumption that workers and firms make decisions about labor supply and labor demand based on the real wage. Thus, the sum of the coefficients on the lagged inflation variables in (1) is restricted to sum to unity $\left(\Sigma c_{i}=1\right)$ to ensure that nominal wages grow in line with prices in the long-run. The second restriction is based on the assumption that the real wages grow in line with labor productivity in the long-run. Thus, the sum of the coefficients on the productivity growth variables in (1) is also restricted to sum to unity $\left(\Sigma d_{i}=1\right){ }^{16}$

${ }^{15}$ Equation (1) is consistent with the original formulation of Phillips (1958) that relates wage growth, rather than price inflation, to the unemployment rate.

${ }^{16} \mathrm{We}$ tested for cointegration between wages, prices and labor productivity, but we were unable to find evidence of a stable long-run equilibrium relationship in terms of levels. This result could reflect our choice of price indices whose coverage does not match that of the nonfarm business sector. Brayton, Roberts and Williams (1999) augment a standard price Phillips curve to include the level of the markup of price over unit labor costs as an error-correction term. However, the construct and significance of the markup requires that a measure of the trend in 
The imposition of the parameter restrictions described above and the evaluation of the wage growth, price inflation, and labor productivity growth series at their steady-state values permits the calculation of a long-run equilibrium, or natural, rate of unemployment. ${ }^{17}$

$$
\overline{(\Delta W-\Delta P)}-\overline{\Delta \theta}=0=a_{0}+\sum_{i} b_{i} U_{t-i}
$$

From (2), the expression for the (constant) value of the natural rate of unemployment is given by:

$$
U^{*}=-\left(a_{0} / \sum_{i} b_{i}\right)
$$

The standard error of the estimate of the natural rate of unemployment in (3) can be constructed using the Delta method which relies on the following asymptotic approximation:

$$
S E\left(U^{*}\right)=\sqrt{\frac{\partial f(\Theta)}{\partial \Theta} \sum \frac{\partial f(\Theta)}{\partial \Theta^{\prime}}}
$$

where $\Theta$ denotes the parameter vector of the model, $\Sigma$ denotes the variance-covariance matrix of the parameter vector, and $f(\Theta)$ is the function mapping the parameter vector $\Theta$ into the expression for the natural rate of unemployment in (3).

productivity enter the calculation and not actual productivity. Thus, there is little evidence in the data suggesting that actual (unadjusted) income shares return to "normal" levels in long-run equilibrium. These considerations justify the specification of the wage equation in (1) in terms of growth rates and not levels.

${ }^{17}$ Because we cast the analysis in terms of a wage Phillips curve and not a price Phillips curve, we will make reference to the natural rate of unemployment rather than the NAIRU. We initially adopt the assumption of a constant natural rate of unemployment because it provides a simple and convenient starting point to evaluate issues pertaining to the stability of the aggregate wage inflation process. 
While equation (1) provides a standard model for analyzing the behavior of aggregate wage inflation, we will consider a more complete version of the model for estimation purposes. In particular, we will extend the equation to incorporate a number of features along the lines suggested in other studies. These extensions are described as follows.

First, we filter the price inflation and productivity growth variables to smooth the series. This procedure provides a parameter reduction scheme for estimation of the model. There are other reasons that motivate this procedure. For example, Brayton, Roberts and Williams (1999) reexamine price-inflation Phillips curves and note that smoothing restrictions lead to the inclusion of longer lags on past inflation. In addition, short-run (quarter-to-quarter) movements in labor productivity are known to be extremely noisy.

For our purposes, we follow the approach of Gordon (1997) and allow past price inflation to enter as a series of four-quarter (moving) averages given by:

$$
\Delta P_{t}^{*}=\sum_{j=0}^{3} \frac{\Delta P_{t-j}}{4}=\frac{\ln \left(P_{t} / P_{t-4}\right)}{4}
$$

In the case of labor productivity, we construct a measure of trend productivity growth $\left(\Delta \theta_{t}^{*}\right)$ that is a j-period (moving) average of quarterly growth rates:

$$
\Delta \theta_{t}^{*}=(1 / j) \sum_{i=0}^{j-1} \Delta \theta_{t-i}=\frac{\ln \left(\theta_{t} / \theta_{t-j}\right)}{j}
$$

We will consider two other extensions of the model. First, we allow for inertia in the wage growth process by including its lagged values. We also augment the explanatory variables to 
include an additional set of labor market variables $\left(z_{t}\right)$. These variables provide a measure of the direct effect of changes in payroll tax rates for Social Security and Medicare as well as a measure of the effective minimum wage. The latter variable is based on Gordon (1985) and is defined as the rate of change in the nominal minimum wage less the one-quarter lagged rate of change in average hourly earnings. ${ }^{18}$ We also consider separate dummy variables to account for the imposition and relaxation of the Nixon wage and price controls during the 1970s. ${ }^{19}$

Our specification for the wage determination process can be summarized as follows:

$$
g(L) \Delta W_{t}=a_{0}+b(L) U_{t}+c(L) \Delta P_{t}^{*}+d(L) \Delta \theta_{t}^{*}+h(L) z_{t}+\epsilon_{t}
$$

For convenience, we will normalize the first element of $g(L)$ to equal unity. With this normalization, we can rewrite the term $g(L) \Delta W_{t}$ as:

$$
g(L) \Delta W_{t}=\Delta W_{t}+g^{\prime}(L) \Delta W_{t-1}=\Delta W_{t}+g_{1}^{\prime} \Delta W_{t-1}+g_{2}^{\prime} \Delta W_{t-2}+\ldots
$$

Substituting equation (8) into (7) yields the following alternative version of the wage equation:

$$
\Delta W_{t}=a_{0}+b(L) U_{t}+c(L) \Delta P_{t}^{*}+d(L) \Delta \theta_{t}^{*}-g^{\prime}(L) \Delta W_{t-1}+h(L) z_{t}+\epsilon_{t}
$$

The modeling restrictions for estimation of the natural rate of unemployment can be recast as:

${ }^{18}$ Our measure of the effective minimum wage differs slightly from that in Gordon (1985) who uses the contemporaneous change in average hourly earnings.

${ }^{19}$ The definition and dating of the dummy variables for the Nixon wage and price controls are taken from Gordon (1982). While the explanatory contribution of the additional labor market variables is relatively small, we include them in the model because of theoretical considerations. 


$$
\begin{aligned}
& 1+\sum_{i} g_{i}^{\prime}=\sum_{i} c_{i}^{\prime} \\
& 1+\sum_{i} g_{i}^{\prime}=\sum_{i} d_{i}^{\prime}
\end{aligned}
$$

The parameter restrictions in (10) can be tested individually as well as jointly. Our extensions require a slight modification to the calculations of the natural rate of unemployment and its standard error previously described in equations (3) and (4), respectively. ${ }^{20}$

Another key aspect of the analysis concerns the stability of the aggregate wage inflation process. To address this issue, we consider a battery of structural break tests developed by Andrews (1993) and Andrews and Ploberger (1994). In particular, we report the Sup (Supremum), Exp (Exponential), and Ave (Average) test statistics based on the Lagrange Multiplier (LM) form version. The testing procedure allows us to examine stability across the whole parameter vector or a subvector. It should be noted, however, that the testing procedure requires some trimming of observations at the beginning and end of the sample. ${ }^{21}$

As previously discussed, an advantage of the Andrews and Andrews/Ploberger structural

${ }^{20} \mathrm{We}$ discuss the modifications in part c) of the Empirical Results section. The models of wage behavior closest in spirit to our formulation are those found in Gordon $(1988,1990,1998)$. However, Gordon examines changes in wage rates relative to trend productivity growth, or trend unit labor costs $\left(\Delta w-\Delta \theta^{*}\right)$. He also uses a different approach to construct the trend productivity measure. Relative to equation (9) and abstracting from issues of variable construction, Gordon's specification imposes restrictions on the coefficients and lag structure of the trend productivity series such that $d_{0}=1$ and $d_{i}=-g_{i}{ }^{\prime}$. While these restrictions may allow for a more straightforward interpretation of the regression model, we find that these restrictions are not supported by the data.

${ }^{21}$ The Sup LM test is based on the largest value of the test statistic calculated at each point within the restricted interval, while the Ave and Exp LM tests are based, respectively, on the arithmetic average and a weighted average of individual values of the test statistic. See Andrews (1993) and Andrews and Ploberger (1994) for further details on the form and construct of the tests. 
break tests is that they do not require the a priori selection of a breakpoint. Rather, the identification of the breakpoint is determined endogenously by evaluating its likelihood at all possible points in the interior of the sample. This feature of the testing procedure is particularly attractive in light of the different views concerning the timing of a possible breakdown in the wage inflation process. It should also be noted that the Andrews and Andrews/Ploberger structural break tests have another desirable property. While the tests are designed to detect an abrupt change in the parameter vector, the tests have power against more general alternatives in which parameters may display a more gradual change over time.

\section{Empirical Results}

The dependent variable is the (annualized) quarterly percent change in nominal compensation per hour for the U.S. nonfarm business sector. We select this wage series because it not only allows for an extended historical analysis, but also accounts for changes in the structure of employment and therefore seems to be the appropriate measure for answering questions about payments to U.S. workers. Based on the approaches of Neumark and Leonard (1993) and Budd and Nho (1997), we use the lagged value of the unemployment rate of prime-age males to measure demand pressure in the labor market. This variable also allows us to control for demographic shifts in the labor force and provides an alternative to constructing an adjusted aggregate measure of the unemployment rate.

We consider three measures for the price inflation series and use the (annualized) quarterly percent change in the overall consumer price index (CPI-U), the personal consumption expenditure (PCE) deflator, and core CPI. While it is our belief that the overall CPI is the most 
relevant measure of price inflation for wage setting decisions, we nevertheless include the other two CPI indexes for comparison purposes. ${ }^{22}$ We include three non-overlapping lagged values of smoothed price inflation so that the series spans a 12 -quarter horizon. ${ }^{23}$ We include the current value of trend labor productivity growth which is measured as the 16-quarter (annualized) change in nonfarm business output per hour. The Data Appendix provides details on these variables as well as the set of additional labor market variables previously discussed in Section III. ${ }^{24}$

\section{A. Model Estimates and Stability}

Table 1 presents the results from estimation of equation (9) over the sample period 1967:Q1-2000:Q2 and measuring price inflation by the CPI-U. The model fits the data quite well and the unemployment rate, lagged inflation, and trend productivity growth terms display the theoretically correct signs. The results also confirm the presence of inertia in the wage inflation series as evidenced by the statistical significance of the lagged wage inflation term. ${ }^{25}$ With the exception of the dummy variable for the imposition of the Nixon wage and price controls, the

${ }^{22}$ Clark (1999) has recently compared the CPI-U and PCE deflator and concludes that the CPI-U is often the better price index when considering the prices faced by individuals. Core CPI excludes the prices of volatile food and energy components. Because workers pay for and presumably care about food and energy prices, the core CPI may be the less relevant price index for wage setting decisions.

${ }^{23}$ Recall from equation (5) that the first smoothed price inflation term is the average of lags $1-4$, the second is the average of lags 5-8, and the third is the average of lags 9-12.

${ }^{24} \mathrm{We}$ formally tested the validity of the smoothing restrictions for the price inflation and labor productivity series. The data did not reject the coefficient restrictions implied by equations (5) and (6) at conventional levels of significance.

${ }^{25}$ The inclusion of lagged wage inflation terms allows us to correct for some slight serial correlation in the regression residuals. Budd and Nho (1997) also find evidence of autocorrelated residuals, but do not include lagged values of wage inflation in their model. Instead, they use the Newey-West (1987) estimator to calculate standard errors for the parameters of the model. 
additional labor market variables are statistically significant at conventional levels. There is also strong support for the proposition that real wages and labor productivity move proportionally in the long-run. In particular, the tests do not reject the individual or joint parameter restrictions across the price inflation, trend labor productivity growth and lagged wage inflation terms.

Table 2 presents the tests for structural change in the model for aggregate nominal compensation growth. ${ }^{26}$ Following the recommendations of Andrews (1993) and Hansen (1997), the Sup test statistic is constructed over the middle 70\% of the sample. The Exp and Ave test statistics are constructed over the middle $80 \%$ of the sample which corresponds to the widest range that allows sufficient degrees of freedom to estimate the parameters of the model. ${ }^{27}$ Because restricting our attention to the entire parameter vector could mask some lower dimensional instability, Table 2 also reports the results for the individual coefficients. In the case of the constant term and the coefficient on the unemployment rate, we also conduct the test imposing the restriction that the structural break date is the same across the parameters. ${ }^{28}$ The identical approach is used in the case of the lagged inflation terms.

The findings in Table 2 provide little evidence that equation (9) displays instability over the sample period. The results are robust across the particular formulation of the test statistic and

\footnotetext{
${ }^{26}$ The equations analyzed for structural breaks in Table 2 (and in subsequent tables) omit the dummy variables for the Nixon wage and price controls. This is because the Andrews and Andrews/Ploberger tests effectively interact dummy variables for different fractions of the sample with the covariates, leading to perfect collinearity. As noted in footnote 19, the estimation results are little affected by the exclusion of these variables.

${ }^{27}$ The sample range is 1971:Q4-1995:Q1 for the Sup test and 1970:Q1-1996:Q4 for the Exp and Ave tests.

${ }^{28}$ This approach follows from the construct of the test for the entire parameter vector which imposes the same structural break date across coefficients.
} 
none of the reported $p$-values indicate a rejection of the null hypothesis of parameter stability at conventional significance levels. While we will turn to a more detailed discussion of the natural rate of unemployment later in this section, it is worth noting that the evidence in Table 2 appears consistent with the assumption that its value remained constant over the sample period.

Specifically, the constant term and the coefficient on the unemployment rate display little evidence of a structural shift when considered individually or together. ${ }^{29}$ A related point is also relevant for the results of Akerlof, Dickens and Perry (2000). In particular, we find little support for the claim that the coefficients on the lagged price inflation terms display instability over the sample. This conclusion again holds regardless of whether we examine the coefficients separately or as a group. Taken together, the evidence in Tables 1-2 suggests that our Phillips curve specification provides a reasonable description of the aggregate U.S. wage inflation process over the past three decades.

Tables 3 and 4 provide the analogous results when price inflation is alternatively measured by the PCE deflator and core CPI. Because we attach far greater significance to the results based on the CPI-U, we think of these findings principally serving a comparison role and providing some insight into the robustness of the results. Nonetheless, the findings in Tables 3-4 are generally consistent with those previously reported for the CPI-U, although there are some differences across the price indices. For example, the use of the PCE deflator generates a markedly lower

\footnotetext{
${ }^{29}$ Admittedly, our conclusion concerning the constancy of the natural rate of unemployment over the sample period needs to be qualified. As shown in equation (3), the natural rate involves a ratio of the estimates of $a_{0}$ and $b_{1}$. Thus, a proper inference concerning the constancy of the natural rate should rely on a test incorporating this nonlinear restriction. However, we did not pursue this issue any further because we were unaware of applications of the Andrews and Andrews/Ploberger testing procedures to nonlinear restrictions. Nevertheless, we are fairly confident that our conclusion is probably reasonable in light of the evidence reported for the constant term and the coefficient on the unemployment rate in Table 2.
} 
coefficient estimate for the trend productivity growth term, resulting in a marginal rejection at the $10 \%$ significance level of the hypothesis that wages fully adjust to movements in labor productivity in the long-run. In addition, the use of the core CPI leads to some evidence of parameter instability, although this result is not robust across different formulations of the test statistic and is altogether absent in the case of the Andrews/Ploberger Ave LM test. ${ }^{30}$

\section{B. Composite Wage Series and Lag Length}

We now consider how variations in the data and model specification may impact on the previous findings. In particular, we will examine how the use of a composite wage measure and shorter lag lengths for the price inflation and labor productivity growth series can affect the inferences drawn about the stability of the model and the validity of the long-run parameter restrictions imposed on the data. To conserve on space, we refrain from reporting estimates of individual parameters and only employ the CPI-U to measure price inflation. ${ }^{31}$

Drawing upon the approach in other studies, we begin by initially considering an alternative wage measure in which we splice compensation per hour and the ECI [wages (and salaries)] at 1980:Q2. This modification constitutes the only change to the previous analysis as we retain all other features of the data and the benchmark model specified in equation (9). Table 5

\footnotetext{
${ }^{30}$ Andrews and Ploberger (1994) argue that the Ave and Exp tests have stronger optimality properties than the Sup test.

${ }^{31}$ Details on the individual parameter estimates and their standard errors are available from the authors upon request. Because of both theoretical and empirical considerations, we view the CPI-U inflation series as providing the most stringent standard to address the concerns of a composite wage measure and lag lengths. We previously argued that the CPI-U was the preferred measure of price inflation. Moreover, the CPI-U yielded the strongest evidence of parameter stability and that real wages and labor productivity grow in line over the long-run. Consequently, we would interpret any subsequent reversal of these conclusions as compelling evidence indicating the importance of these concerns.
} 
presents the Andrews and Andrews/Ploberger tests for structural change as well as the tests of the long-run parameter restrictions between the wage inflation, price inflation and trend labor productivity growth series.

In contrast to the results reported in Table 2, there is clear evidence across the test statistics of model instability. The evidence is particularly strong in the case of the coefficients on the lagged inflation terms. This finding is now consistent with that of Akerlof, Dickens and Perry (2000) who also employ a composite wage measure, although our analysis uncovers additional parameter instability that is absent from their study. ${ }^{32}$ Thus, the use of a composite wage measure can be a contributing factor to parameter instability in estimated wage Phillips curves. ${ }^{33}$ Abstracting from the issue of parameter instability, however, it is interesting to note that the composite wage measure does not lead to a rejection of the hypothesis that real wages and labor productivity move proportionally in the long-run.

To gain some insight into the nature of the instability, Figure 1 plots the value of the Andrews (1993) Sup LM test statistic for the null hypothesis of no break in the full parameter

${ }^{32}$ Akerlof, Dickens and Perry (2000) actually splice average hourly earnings (AHE) and the ECI. Unlike the results based on compensation per hour, we found strong evidence of parameter instability regardless of whether we used the AHE or the AHE-ECI series as the dependent variable. Consequently, the practice of splicing alternative wage series may be less relevant for parameter instability in the case of AHE. However, we do not view AHE as the appropriate wage measure for this study. While AHE has an advantage in current analysis of being reported on a monthly basis with only a short lag, it mixes wage change and workforce composition in its construct. Thus, it does not provide a good gauge of only wage changes.

${ }^{33}$ We obtained similar results splicing compensation per hour and the total ECI [wages (and salaries) and benefits] measure. 
vector at each interior point. ${ }^{34}$ The figure displays a single peak and indicates a fairly narrow range of possible breakpoints in the early 1980s, with the strongest evidence associated with 1980:Q1. A similar conclusion about possible breakpoints emerges from Table 6 which reports the dates associated with the largest value of the Andrews (1993) Sup LM test for the individual parameters in the model. ${ }^{35}$ Taken together, Figure 1 and Table 6 provide strong evidence that the model employing the composite wage measure displays a structural break in the 1980-83 range. This finding most likely reflects the fact that we splice the compensation per hour and ECI series at 1980:Q2.

Our analysis now turns to the issue of lag length for the price inflation and trend labor productivity growth series. Drawing upon the work of Budd and Nho (1997), we will now modify the benchmark model specified in equation (9) by restricting these variables to enter only as yearover year (four-quarter) percentage changes. ${ }^{36}$ That is, each variable is measured as an average of quarterly growth rates over a single one-year horizon. Table 7 presents the Andrews and Andrews/Ploberger tests for structural change as well as the tests of the long-run parameter restrictions between wages, prices, and labor productivity.

Similar to the results reported in Table 5, there is again strong evidence across the test

${ }^{34}$ The construct of the Sup LM test allows for a direct estimate of the breakpoint. The Exp and Ave LM tests, however, are based on a function of the individual test statistics and only generate a single value over any restricted estimation interval. Consequently, the Exp and Ave LM tests cannot be used by themselves to identify the breakpoint.

${ }^{35}$ As noted, we also report the results when we impose the restriction that the structural break date is the same across the constant term and the coefficient on the unemployment rate as well as the lagged inflation terms.

${ }^{36}$ We are actually considering a slight variant of Budd and Nho (1997) who only include the growth rate for each variable measured over a one-quarter horizon. 
statistics of model instability. While the coefficient on the trend labor productivity growth series appears stable over the sample period, the constant term as well as the coefficients on the unemployment rate, price inflation and lagged wage inflation series display instability. With regard to the issue of a long-run relationship between wages, prices and labor productivity, there is now an overwhelming rejection of the individual as well as joint parameter restrictions. We also relaxed the smoothing restrictions by including the four quarterly price inflation and labor productivity growth terms as individual regressors. This led to very little change in terms of the pattern of parameter instability or in the rejection of the long-run parameter restrictions. ${ }^{37}$

Following the previous analysis for the composite wage model, Figure 2 plots the value of the Andrews (1993) Sup LM test statistics for the null hypothesis of no break in the full parameter vector at each interior point. The pattern of the test statistics for the wage model incorporating shorter lag lengths for the price inflation and labor productivity growth series displays the same single and narrow peak evident in Figure 1. However, the test statistics now identify a breakdown in the wage Phillips curve model in the late 1980s, with the strongest evidence occurring at 1988:Q3. This same dating scheme is evident from Table 8 which reports the dates associated with the largest value of the Andrews (1993) Sup test for the individual parameters in the model. Specifically, the majority of the break dates are confined to the period 1987-88. Interestingly, Katz and Krueger (1999) adopt a similar model specification and then provide evidence of a favorable shift in the wage Phillips curve since 1988. Our results suggest that the apparent shift may instead be an artifact of the short lag lengths selected for the price inflation and labor

\footnotetext{
${ }^{37}$ Budd and Nho (1997) also report evidence of instability in estimated wage Phillips curves, although they claim that the instability principally stems from a structural shift in the constant term.
} 
productivity growth series.

There is one additional point worth noting about the pattern of the test statistics depicted in Figures 1-2. Specifically, neither graph seems to indicate heightened instability in the wage inflation process during the 1990s. The values of the test statistic are well below the maximum and there is little evidence of a pronounced rise during this decade. These same features are also evident in the case of the benchmark model..$^{38}$ Admittedly, some caution is needed in interpreting these results due to the trimming of observations at the end (and beginning) of the sample. Nevertheless, the overall evidence with regard to the dating of the structural breakpoints as well as the behavior of the test statistics seems inconsistent with claims that the 1990s witnessed the emergence of a "New Economy" and a fundamental change in the labor market. Moreover, we have little reason to believe that our view will change with the arrival of additional data.

\section{The Natural Rate of Unemployment: Estimates and Precision}

The evidence from the Andrews and Andrews/Ploberger structural break tests reported in Table 2 and Table 4 indicates that the aggregate U.S. wage inflation process has remained stable over the last thirty years. Because this evidence extends to include the constant term and the coefficient on the unemployment rate in the wage Phillips curve, our findings offer support for the claim that the natural rate of unemployment remained constant over the sample period. ${ }^{39}$

\footnotetext{
${ }^{38} \mathrm{We}$ did not generate plots of the test statistics for the benchmark model in Table 2 and Table 4 because the results did not indicate parameter instability. While the pattern of the test statistics was not robust across the choice of the price inflation series, there was little evidence indicating a marked change in their behavior toward the end of the restricted estimation interval. For example, the CPI-U generated the strongest evidence for a break in 1988 and 1992, while the core CPI almost uniformly pointed to 1971:Q4. In contrast, there was no discernible pattern for the PCE deflator.

${ }^{39}$ See the previous discussion in footnote 29.
} 
Consequently, we now turn to a discussion of the estimates of the natural rate of unemployment and their precision.

To estimate the natural rate of unemployment, we rely on the benchmark specification for the wage determination process in equation (9) as well as on two additional considerations. First, we impose the parameter restrictions in equation (10) relating to the long-run relationship between wages, prices and labor productivity. Second, we normalize the set of labor market variables in $z_{t}$ by expressing each variable as a deviation from its mean. ${ }^{40}$ Using the model estimates, we then calculate the (constant) value of the natural rate of unemployment according to equation (3) and construct the corresponding confidence interval using equation (4).

Table 9 presents the point estimate and 95 percent confidence interval for the natural rate of unemployment (for prime-age males). For comparison purposes, we report the estimate and confidence interval using the CPI-U, PCE deflator and core CPI to measure price inflation. As shown, the results are very similar for the CPI-U and core CPI inflation series which generate estimates of the natural of unemployment of $3.2 \%$ and $3.1 \%$, respectively. On the other hand, the PCE deflator generates a higher point estimate of $3.8 \%$.

There are two other important aspects to the findings in Table 9. First, our estimates of the natural rate of unemployment appear to be more precisely estimated than those obtained from price inflation Phillips curves. For example, Staiger, Stock and Watson (1997) report 95 percent

${ }^{40}$ This normalization was applied to the effective minimum wage and the payroll taxes for Social Security and Medicare, but not to the dummy variables for the wage and price controls. Borrowing from the terminology in Gordon (1988), the normalization allows us to construct an estimate of the "no-shock" natural rate of unemployment that holds constant the influence of changes in the minimum wage and payroll taxes in the sample period. 
confidence intervals for NAIRU estimates that typically display a range of almost 2 percent. ${ }^{41}$ While a further exploration into this issue is beyond the scope of the current paper, the enhanced precision of the natural rate estimates could reflect a variety of factors relating to model specification, sample period, or even the fact that the estimation is cast in terms of nominal wage inflation rather than price inflation. Second, Figure 3 suggests that the unemployment rate of prime-age males has only recently begun to approach the lower bound of the 95 percent confidence interval for the natural rate of unemployment. Consequently, claims of an extraordinarily 'tight' labor market and concerns about an impending acceleration in nominal wage growth would seem to have been largely unfounded up until very recently.

\section{Conclusion}

This study finds little empirical evidence of a breakdown in the wage Phillips curve over the course of the last three decades. While this conclusion technically cannot be extended to include the last three years, the tests for parameter stability provide little support for previous claims of structural change in the labor market and unusual wage restraint in the early as well as late 1980s. Our view would seem to be strengthened by the model of the wage inflation process displaying a highly significant relationship with its posited key determinants and providing support for the hypothesis that real wages and labor productivity move proportionally in the long-run.

We find a close association between evidence of significant structural change and issues concerning the construction of the wage measure and model specification. Compared to the performance of our benchmark wage Phillips curve, the adoption of a composite wage measure or

\footnotetext{
${ }^{41}$ See Table 1 in Staiger, Stock and Watson (1997).
} 
the failure to incorporate sufficient lags of price inflation and labor productivity growth can generate strong evidence of parameter instability. The relationship between parameter instability and lag length seems to be especially important in the case of the price inflation series.

While the analysis is largely agnostic about a possible change in the inflationunemployment relationship, our results nevertheless have some bearing on recent discussions of this issue. For example, the absence of structural change in the labor market would seem to offer enhanced credibility to arguments claiming that transitory factors are responsible for the "inflation puzzle". However, if the "inflation puzzle" is truly indicative of a fundamental shift in the inflation-unemployment relationship, then our findings would suggest that such a change would likely stem from developments in product and/or financial markets. 


\section{Table 1}

$$
\Delta W_{t}=a_{0}+b(L) U_{t}+c(L) \Delta P_{t}^{*}+d_{0} \Delta \theta_{t}^{*}-g^{\prime}(L) \Delta W_{t-1}+h(L) z_{t}+\epsilon_{t}
$$

\begin{tabular}{|l|c|l|l|}
\hline Price Index: CPI-U & & & \\
\hline $\begin{array}{l}\text { Sample Period } \\
1967: \mathrm{Q} 1-2000: \mathrm{Q} 2\end{array}$ & $\begin{array}{c}\bar{R}^{2}=0.7215 \\
\mathrm{SEE}=1.4533\end{array}$ & & \\
\hline Parameter & Estimated Coefficient & Parameter & Estimated Coefficient \\
\hline \hline$a_{0}$ & $\begin{array}{c}2.2662^{* *} \\
(0.8664)\end{array}$ & $g_{2}^{\prime}$ & $\begin{array}{c}-0.1378^{*} \\
(0.0761)\end{array}$ \\
\hline$b_{1}$ & $\begin{array}{c}-0.6166^{* * *} \\
(0.1307)\end{array}$ & $h_{0}^{\text {Minimum wage }}$ & $\begin{array}{c}0.0425^{*} * * \\
(0.0097)\end{array}$ \\
\hline$c_{1}$ & $\begin{array}{c}0.3813 * * * \\
(0.0897)\end{array}$ & $h_{0}^{\text {Social Security }}$ & $\begin{array}{c}0.2590^{* * *} \\
(0.0653)\end{array}$ \\
\hline$c_{5}$ & $\begin{array}{c}0.1793 \\
(0.1084)\end{array}$ & $h_{0}^{\text {NIXON }}$ & $\begin{array}{c}-0.7397 \\
(0.9168)\end{array}$ \\
\hline$c_{9}$ & $\begin{array}{c}0.2497 * * * \\
(0.0860)\end{array}$ & $h_{0}^{\text {NIXOFF }}$ & $\begin{array}{c}0.7370 * * \\
(0.3365)\end{array}$ \\
\hline$d_{0}$ & $\begin{array}{c}0.7922^{*} * * \\
(0.2335)\end{array}$ & & \\
\hline
\end{tabular}

\begin{tabular}{|l|l|l|}
\hline Restriction & Value of Test Statistic & p-Value \\
\hline $1+\Sigma g^{\prime}=\Sigma c$ & $\chi^{2}(1)=0.603$ & 0.4372 \\
\hline $1+\Sigma g^{\prime}=d_{0}$ & $\chi^{2}(1)=0.104$ & 0.7466 \\
\hline $\begin{array}{l}1+\Sigma g^{\prime}=\Sigma c \\
1+\Sigma g^{\prime}=d_{0}\end{array}$ & $\chi^{2}(2)=0.607$ & 0.7380 \\
\hline
\end{tabular}

Note: Heteroskedasticity-consistent standard errors are reported in parentheses.

* Significant at the 10 percent level

** Significant at the 5 percent level.

*** Significant at the 1 percent level 
Table 2

\begin{tabular}{|c|c|c|c|}
\hline Price Index: CPI-L & & & \\
\hline Parameter & $\begin{array}{l}\text { Andrews/Quandt } \\
\text { Supremum LM Test } \\
\text { (Middle 70\%) } \\
\end{array}$ & $\begin{array}{l}\text { Andrews/Ploberger } \\
\text { Exponential LM Test } \\
\text { (Middle 80\%) } \\
\end{array}$ & $\begin{array}{l}\text { Andrews/Ploberger } \\
\text { Average LM Test } \\
\text { (Middle } 80 \% \text { ) }\end{array}$ \\
\hline Parameter Vector & $\begin{array}{c}16.624 \\
(0.460)\end{array}$ & $\begin{array}{c}6.125 \\
(0.391)\end{array}$ & $\begin{array}{r}10.289 \\
(0.273)\end{array}$ \\
\hline$a_{0}$ & $\begin{array}{c}3.274 \\
(0.499)\end{array}$ & $\begin{array}{c}0.435 \\
(0.521)\end{array}$ & $\begin{array}{c}0.687 \\
(0.524)\end{array}$ \\
\hline$b_{1}$ & $\begin{array}{c}4.469 \\
(0.309)\end{array}$ & $\begin{array}{c}0.551 \\
(0.422)\end{array}$ & $\begin{array}{c}0.822 \\
(0.438)\end{array}$ \\
\hline$c_{1}$ & $\begin{array}{c}5.341 \\
(0.213)\end{array}$ & $\begin{array}{c}0.877 \\
(0.245)\end{array}$ & $\begin{array}{c}1.149 \\
(0.287)\end{array}$ \\
\hline$c_{5}$ & $\begin{array}{c}3.212 \\
(0.511)\end{array}$ & $\begin{array}{c}0.341 \\
(0.624)\end{array}$ & $\begin{array}{c}0.530 \\
(0.646)\end{array}$ \\
\hline$c_{9}$ & $\begin{array}{c}4.422 \\
(0.315)\end{array}$ & $\begin{array}{c}0.471 \\
(0.487)\end{array}$ & $\begin{array}{c}0.682 \\
(0.527)\end{array}$ \\
\hline$d_{0}$ & $\begin{array}{c}3.111 \\
(0.531)\end{array}$ & $\begin{array}{c}0.552 \\
(0.421)\end{array}$ & $\begin{array}{c}0.974 \\
(0.359)\end{array}$ \\
\hline$g_{2}^{\prime}$ & $\begin{array}{c}4.000 \\
(0.374)\end{array}$ & $\begin{array}{c}0.514 \\
(0.451)\end{array}$ & $\begin{array}{c}0.776 \\
(0.465)\end{array}$ \\
\hline$h_{0}^{\text {Minimum wage }}$ & $\begin{array}{c}1.472 \\
(0.914)\end{array}$ & $\begin{array}{c}0.231 \\
(0.781)\end{array}$ & $\begin{array}{c}0.423 \\
(0.742)\end{array}$ \\
\hline$h_{0}^{\text {Social Security }}$ & $\begin{array}{c}4.899 \\
(0.258)\end{array}$ & $\begin{array}{c}1.004 \\
(0.202)\end{array}$ & $\begin{array}{c}1.449 \\
(0.199)\end{array}$ \\
\hline$\left[a_{0}, b_{1}\right]$ & $\begin{array}{c}6.983 \\
(0.295)\end{array}$ & $\begin{array}{c}1.226 \\
(0.436)\end{array}$ & $\begin{array}{c}1.457 \\
(0.593)\end{array}$ \\
\hline$\left[c_{1}, c_{5}, c_{9}\right]$ & $\begin{array}{l}10.169 \\
(0.200)\end{array}$ & $\begin{array}{c}2.815 \\
(0.197)\end{array}$ & $\begin{array}{c}4.156 \\
(0.185)\end{array}$ \\
\hline
\end{tabular}

Note: Values of the test statistic are reported in columns 2-4, with asymptotic $p$-values reported below in parentheses.

* Significant at the 10 percent level

** Significant at the 5 percent level.

***Significant at the 1 percent level 
Table 3

$$
\Delta W_{t}=a_{0}+b(L) U_{t}+c(L) \Delta P_{t}^{*}+d_{0} \Delta \theta_{t}^{*}-g^{\prime}(L) \Delta W_{t-1}+h(L) z_{t}+\epsilon_{t}
$$

\begin{tabular}{|c|c|c|}
\hline & Price Index: PCE Deflator & Price Index: Core CPI \\
\hline $\begin{array}{l}\text { Sample Period } \\
\text { 1967:Q1 - 2000:Q2 }\end{array}$ & $\begin{array}{l}\bar{R}^{2}=0.7264 \\
\mathrm{SEE}=1.4403\end{array}$ & $\begin{array}{l}\bar{R}^{2}=0.7021 \\
\mathrm{SEE}=1.5030\end{array}$ \\
\hline Parameter & Estimated Coefficient & Estimated Coefficient \\
\hline$a_{0}$ & $\begin{array}{c}3.0390 * * * \\
(0.8033)\end{array}$ & $\begin{array}{l}1.8835^{* *} \\
(0.8289)\end{array}$ \\
\hline$b_{1}$ & $\begin{array}{c}-0.6975 * * * \\
(0.1236)\end{array}$ & $\begin{array}{c}-0.6896 * * * \\
(0.1245)\end{array}$ \\
\hline$c_{1}$ & $\begin{array}{c}0.4134 * * * \\
(0.1017)\end{array}$ & $\begin{array}{c}0.4271 * * * \\
(0.0968)\end{array}$ \\
\hline$c_{5}$ & $\begin{array}{l}0.2603 * * \\
(0.1249)\end{array}$ & $\begin{array}{l}0.2858 * * * \\
(0.0804)\end{array}$ \\
\hline$c_{9}$ & $\begin{array}{l}0.2327 * * \\
(0.0921)\end{array}$ & $\begin{array}{l}0.1834 * * \\
(0.0706)\end{array}$ \\
\hline$d_{0}$ & $\begin{array}{l}0.5216 * * \\
(0.2135)\end{array}$ & $\begin{array}{l}0.8043 * * * \\
(0.2399)\end{array}$ \\
\hline$g_{2}^{\prime}$ & $\begin{array}{l}-0.1425 * \\
(0.0764)\end{array}$ & $\begin{array}{c}-0.1680 * * \\
(0.0759)\end{array}$ \\
\hline$h_{0}^{\text {Minimum wage }}$ & $\begin{array}{c}0.0440 * * * \\
(0.0092)\end{array}$ & $\begin{array}{l}0.0504 * * * \\
(0.0085)\end{array}$ \\
\hline$h_{0}^{\text {Social Security }}$ & $\begin{array}{l}0.2488 * * * \\
(0.0538)\end{array}$ & $\begin{array}{c}0.2693 * * * \\
(0.0640)\end{array}$ \\
\hline$h_{0}^{N I X O N}$ & - & $\begin{array}{l}-0.9088 \\
(0.9395)\end{array}$ \\
\hline$h_{0}^{\text {NIXOFF }}$ & $-\ldots$ & $\begin{array}{c}1.5733 * * * \\
(0.3983)\end{array}$ \\
\hline
\end{tabular}

Note: Heteroskedasticity-consistent standard errors are reported in parentheses.

* Significant at the 10 percent level

** Significant at the 5 percent level.

***Significant at the 1 percent level 
Table 3 (continued)

$$
\Delta W_{t}=a_{0}+b(L) U_{t}+c(L) \Delta P_{t}^{*}+d_{0} \Delta \theta_{t}^{*}-g^{\prime}(L) \Delta W_{t-1}+h(L) z_{t}+\epsilon_{t}
$$

\begin{tabular}{|c|c|c|c|c|}
\hline \multirow[b]{2}{*}{ Restriction } & \multicolumn{2}{|c|}{ Price Index: PCE Deflator } & \multicolumn{2}{|c|}{ Price Index: Core CPI } \\
\hline & $\begin{array}{l}\text { Value of } \\
\text { Test Statistic }\end{array}$ & p-Value & $\begin{array}{l}\text { Value of } \\
\text { Test Statistic }\end{array}$ & p-Value \\
\hline $1+\Sigma g^{\prime}=\Sigma c$ & $\chi^{2}(1)=0.538$ & 0.4630 & $\chi^{2}(1)=0.647$ & 0.4211 \\
\hline $1+\Sigma g^{\prime}=d_{0}$ & $\chi^{2}(1)=2.739^{*}$ & 0.0978 & $\chi^{2}(1)=0.015$ & 0.8999 \\
\hline $\begin{aligned} 1+\Sigma g^{\prime} & =\Sigma c \\
1+\Sigma g^{\prime} & =d_{0}\end{aligned}$ & $\chi^{2}(2)=4.268$ & 0.1183 & $\chi^{2}(2)=0.885$ & 0.6423 \\
\hline
\end{tabular}

* Significant at the 10 percent level

** Significant at the 5 percent level.

*** Significant at the 1 percent level 
Table 4

\begin{tabular}{|c|c|c|c|c|c|c|}
\hline \multirow[b]{2}{*}{ Parameter } & \multicolumn{2}{|c|}{$\begin{array}{l}\text { Andrews/Quandt } \\
\text { Supremum LM Test } \\
\text { (Middle 70\%) }\end{array}$} & \multicolumn{2}{|c|}{$\begin{array}{l}\text { Andrews/Ploberger } \\
\text { Exponential LM Test } \\
\text { (Middle 80\%) }\end{array}$} & \multicolumn{2}{|c|}{$\begin{array}{l}\text { Andrews/Ploberger } \\
\text { Average LM Test } \\
\text { (Middle 80\%) }\end{array}$} \\
\hline & $\begin{array}{l}\text { PCE } \\
\text { Deflator }\end{array}$ & $\begin{array}{l}\text { Core } \\
\text { CPI }\end{array}$ & $\begin{array}{l}\text { PCE } \\
\text { Deflator }\end{array}$ & $\begin{array}{l}\text { Core } \\
\text { CPI }\end{array}$ & $\begin{array}{l}\text { PCE } \\
\text { Deflator }\end{array}$ & $\begin{array}{l}\text { Core } \\
\text { CPI }\end{array}$ \\
\hline Parameter Vector & $\begin{array}{l}16.910 \\
(0.436)\end{array}$ & $\begin{array}{l}18.136 \\
(0.340)\end{array}$ & $\begin{array}{c}6.473 \\
(0.327)\end{array}$ & $\begin{array}{c}5.890 \\
(0.438)\end{array}$ & $\begin{array}{l}11.595 \\
(0.154)\end{array}$ & $\begin{array}{c}8.469 \\
(0.525)\end{array}$ \\
\hline$a_{0}$ & $\begin{array}{c}2.092 \\
(0.762) \\
\end{array}$ & $\begin{array}{c}8.849 * * \\
(0.044) \\
\end{array}$ & $\begin{array}{r}0.386 \\
(0.572) \\
\end{array}$ & $\begin{array}{c}1.325 \\
(0.127) \\
\end{array}$ & $\begin{array}{r}0.690 \\
(0.521) \\
\end{array}$ & $\begin{array}{c}1.078 \\
(0.314) \\
\end{array}$ \\
\hline$b_{1}$ & $\begin{array}{c}2.381 \\
(0.692)\end{array}$ & $\begin{array}{l}8.353^{*} \\
(0.056)\end{array}$ & $\begin{array}{c}0.424 \\
(0.531)\end{array}$ & $\begin{array}{c}1.092 \\
(0.177)\end{array}$ & $\begin{array}{c}0.741 \\
(0.487)\end{array}$ & $\begin{array}{c}1.049 \\
(0.326)\end{array}$ \\
\hline$c_{1}$ & $\begin{array}{c}3.495 \\
(0.458) \\
\end{array}$ & $\begin{array}{l}8.149^{*} \\
(0.061) \\
\end{array}$ & $\begin{array}{c}0.451 \\
(0.506) \\
\end{array}$ & $\begin{array}{c}1.416 \\
(0.112) \\
\end{array}$ & $\begin{array}{c}0.692 \\
(0.520) \\
\end{array}$ & $\begin{array}{c}1.211 \\
(0.266) \\
\end{array}$ \\
\hline$c_{5}$ & $\begin{array}{c}1.476 \\
(0.913)\end{array}$ & $\begin{array}{c}6.802 \\
(0.112)\end{array}$ & $\begin{array}{c}0.262 \\
(0.732)\end{array}$ & $\begin{array}{c}0.738 \\
(0.306)\end{array}$ & $\begin{array}{c}0.484 \\
(0.686)\end{array}$ & $\begin{array}{c}0.848 \\
(0.423)\end{array}$ \\
\hline$c_{9}$ & $\begin{array}{c}2.602 \\
(0.640) \\
\end{array}$ & $\begin{array}{l}8.017^{*} \\
(0.065) \\
\end{array}$ & $\begin{array}{c}0.399 \\
(0.557) \\
\end{array}$ & $\begin{array}{c}1.029 \\
(0.194) \\
\end{array}$ & $\begin{array}{c}0.704 \\
(0.512) \\
\end{array}$ & $\begin{array}{c}1.067 \\
(0.318) \\
\end{array}$ \\
\hline$d_{0}$ & $\begin{array}{c}4.837 \\
(0.264)\end{array}$ & $\begin{array}{c}9.776 * * \\
(0.029)\end{array}$ & $\begin{array}{c}1.031 \\
(0.194)\end{array}$ & $\begin{array}{l}1.684^{*} \\
(0.079)\end{array}$ & $\begin{array}{c}1.628 \\
(0.161)\end{array}$ & $\begin{array}{c}1.137 \\
(0.291)\end{array}$ \\
\hline$g_{2}^{\prime}$ & $\begin{array}{c}3.582 \\
(0.442)\end{array}$ & $\begin{array}{c}10.359 * * \\
(0.022)\end{array}$ & $\begin{array}{c}0.693 \\
(0.331)\end{array}$ & $\begin{array}{l}2.029^{*} \\
(0.051)\end{array}$ & $\begin{array}{c}1.147 \\
(0.288)\end{array}$ & $\begin{array}{c}1.386 \\
(0.214)\end{array}$ \\
\hline$h_{0}^{\text {Minimum wage }}$ & $\begin{array}{c}2.035 \\
(0.776)\end{array}$ & $\begin{array}{c}3.280 \\
(0.497)\end{array}$ & $\begin{array}{c}0.342 \\
(0.623)\end{array}$ & $\begin{array}{c}0.589 \\
(0.394)\end{array}$ & $\begin{array}{c}0.613 \\
(0.578)\end{array}$ & $\begin{array}{c}0.988 \\
(0.352)\end{array}$ \\
\hline$h_{0}^{\text {Social Security }}$ & $\begin{array}{c}3.964 \\
(0.379)\end{array}$ & $\begin{array}{c}4.606 \\
(0.291)\end{array}$ & $\begin{array}{c}0.772 \\
(0.290)\end{array}$ & $\begin{array}{c}0.961 \\
(0.215)\end{array}$ & $\begin{array}{c}1.158 \\
(0.284)\end{array}$ & $\begin{array}{c}1.462 \\
(0.196)\end{array}$ \\
\hline$\left[a_{0}, b_{1}\right]$ & $\begin{array}{c}8.701 \\
(0.157)\end{array}$ & $\begin{array}{c}9.010 \\
(0.139)\end{array}$ & $\begin{array}{c}1.878 \\
(0.214)\end{array}$ & $\begin{array}{c}1.712 \\
(0.257)\end{array}$ & $\begin{array}{c}1.815 \\
(0.451)\end{array}$ & $\begin{array}{c}1.970 \\
(0.398)\end{array}$ \\
\hline$\left[c_{1}, c_{5}, c_{9}\right]$ & $\begin{array}{c}8.452 \\
(0.348)\end{array}$ & $\begin{array}{c}13.060^{*} \\
(0.069)\end{array}$ & $\begin{array}{c}2.364 \\
(0.296)\end{array}$ & $\begin{array}{c}3.421 \\
(0.112)\end{array}$ & $\begin{array}{c}3.910 \\
(0.221)\end{array}$ & $\begin{array}{c}3.575 \\
(0.278)\end{array}$ \\
\hline
\end{tabular}

Note: Values of the test statistic are reported in columns 2-7, with asymptotic $p$-values reported below in parentheses.

* Significant at the 10 percent level

** Significant at the 5 percent level.

$* * *$ Significant at the 1 percent level 
Table 5

$$
\Delta W_{t}^{\text {Spliced }}=a_{0}+b(L) U_{t}+c(L) \Delta P_{t}^{*}+d_{0} \Delta \theta_{t}^{*}-g(L)^{\prime} \Delta W_{t-1}^{\text {Spliced }}+h(L) z_{t}+\epsilon_{t}
$$

\begin{tabular}{|c|c|c|c|}
\hline \multicolumn{4}{|c|}{ Wage Series: Spliced Compensation Per Hour and ECI (Price Index: CPI-U) } \\
\hline Parameter & $\begin{array}{l}\text { Andrews/Quandt } \\
\text { Supremum LM Test } \\
\text { (Middle 70\%) }\end{array}$ & $\begin{array}{l}\text { Andrews/Ploberger } \\
\text { Exponential LM Test } \\
\text { (Middle 80\%) }\end{array}$ & $\begin{array}{l}\text { Andrews/Ploberger } \\
\text { Average LM Test } \\
\text { (Middle 80\%) }\end{array}$ \\
\hline Parameter Vector & $\begin{array}{c}26.722^{* * *} \\
(0.031)\end{array}$ & $\begin{array}{c}9.863 * * \\
(0.037)\end{array}$ & $\begin{array}{c}12.804 * \\
(0.086)\end{array}$ \\
\hline$a_{0}$ & $\begin{array}{l}9.200 * * \\
(0.038)\end{array}$ & $\begin{array}{c}2.352^{* * *} \\
(0.034)\end{array}$ & $\begin{array}{l}2.967 * * \\
(0.040)\end{array}$ \\
\hline$b_{1}$ & $\begin{array}{c}9.072 * * \\
(0.040)\end{array}$ & $\begin{array}{l}1.893^{*} \\
(0.060)\end{array}$ & $\begin{array}{l}2.183^{*} \\
(0.088)\end{array}$ \\
\hline$c_{1}$ & $\begin{array}{c}14.322^{* * * *} \\
(0.003)\end{array}$ & $\begin{array}{c}4.053 * * * \\
(0.002)\end{array}$ & $\begin{array}{l}4.429^{*} \\
(0.010)\end{array}$ \\
\hline$c_{5}$ & $\begin{array}{l}9.259^{* * *} \\
(0.037)\end{array}$ & $\begin{array}{c}2.400 * * \\
(0.032)\end{array}$ & $\begin{array}{l}2.788^{* * *} \\
(0.048)\end{array}$ \\
\hline$c_{9}$ & $\begin{array}{c}12.020 * * * \\
(0.010)\end{array}$ & $\begin{array}{c}2.819 * * \\
(0.018)\end{array}$ & $\begin{array}{l}2.693 * \\
(0.052)\end{array}$ \\
\hline$d_{0}$ & $\begin{array}{l}7.169^{*} \\
(0.095)\end{array}$ & $\begin{array}{l}1.634 * \\
(0.084)\end{array}$ & $\begin{array}{l}2.266^{*} \\
(0.080)\end{array}$ \\
\hline$g_{2}^{\prime}$ & $\begin{array}{c}11.076 * * \\
(0.015)\end{array}$ & $\begin{array}{l}3.108^{* * *} \\
(0.012)\end{array}$ & $\begin{array}{l}3.691 * * \\
(0.020)\end{array}$ \\
\hline$h_{0}^{\text {Minimum wage }}$ & $\begin{array}{c}5.332 \\
(0.214)\end{array}$ & $\begin{array}{l}1.604 * \\
(0.088)\end{array}$ & $\begin{array}{l}2.630^{*} \\
(0.056)\end{array}$ \\
\hline$h_{0}^{\text {Social Security }}$ & $\begin{array}{c}4.963 \\
(0.251)\end{array}$ & $\begin{array}{c}1.364 \\
(0.121)\end{array}$ & $\begin{array}{l}2.061^{*} \\
(0.100)\end{array}$ \\
\hline$\left[a_{0}, b_{1}\right]$ & $\begin{array}{c}9.391 \\
(0.120)\end{array}$ & $\begin{array}{c}2.532 \\
(0.104)\end{array}$ & $\begin{array}{c}3.388 \\
(0.122)\end{array}$ \\
\hline$\left[c_{1}, c_{5}, c_{9}\right]$ & $\begin{array}{c}16.500 * * \\
(0.016)\end{array}$ & $\begin{array}{l}5.128^{* * *} \\
(0.023)\end{array}$ & $\begin{array}{l}6.442 * * \\
(0.032)\end{array}$ \\
\hline
\end{tabular}

Note: Values of the test statistic are reported in columns 2-4, with asymptotic $p$-values reported below in parentheses.

* Significant at the 10 percent level

** Significant at the 5 percent level.

*** Significant at the 1 percent level 


\section{Table 5 (continued)}

\begin{tabular}{|l|l|l|}
\hline \multicolumn{2}{|c|}{ Wage Series: Spliced Compensation Per Hour and ECI (Price Index: CPI-U) } \\
\hline Restriction & Value of Test Statistic & p-Value \\
\hline \hline $1+\Sigma g^{\prime}=\Sigma c$ & $\chi^{2}(1)=0.679$ & 0.4098 \\
\hline $1+\Sigma g^{\prime}=d_{0}$ & $\chi^{2}(1)=0.00$ & 0.9925 \\
\hline $\begin{array}{l}1+\Sigma g^{\prime}=\Sigma c \\
1+\Sigma g^{\prime}=d_{0}\end{array}$ & $\chi^{2}(2)=0.812$ & 0.6661 \\
\hline
\end{tabular}

* Significant at the 10 percent level ** Significant at the 5 percent level. *** Significant at the 1 percent level 


\section{FIGURE 1}

Supremum LM Statistic: Spliced Wage Model

(Level)

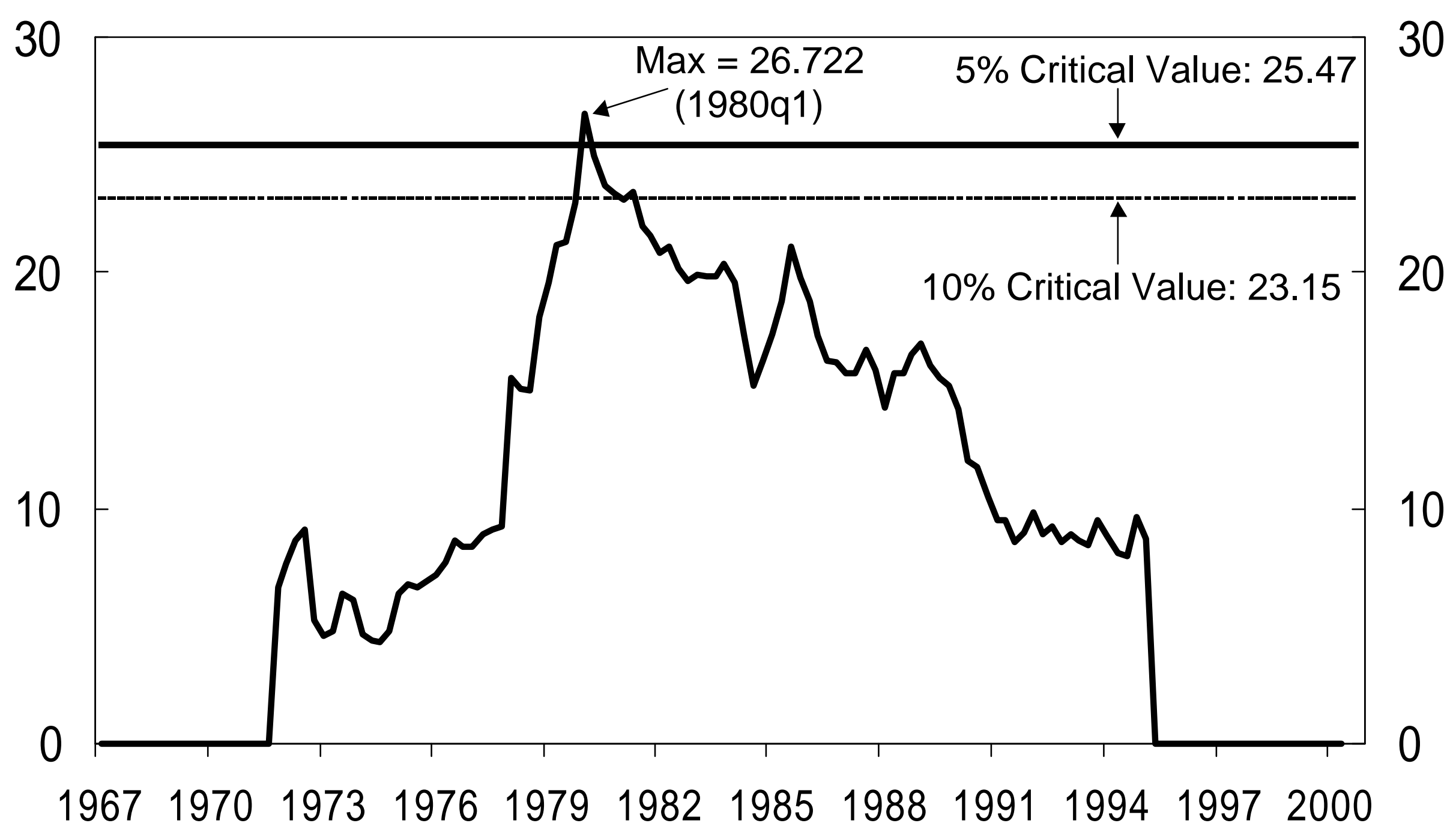




\section{Table 6}

Selected Break Dates Across the Composite Wage Model

\begin{tabular}{|l|l|}
\hline Parameter & Break Date \\
\hline \hline Parameter Vector & $1980: \mathrm{Q} 1$ \\
\hline$a_{0}$ & $1980: \mathrm{Q} 1$ \\
\hline$b_{1}$ & $1983: \mathrm{Q} 4$ \\
\hline$c_{1}$ & $1980: \mathrm{Q} 1$ \\
\hline$c_{5}$ & $1985: \mathrm{Q} 3$ \\
\hline$c_{9}$ & $1983: \mathrm{Q} 4$ \\
\hline$d_{0}$ & $1983: \mathrm{Q} 4$ \\
\hline$g_{2}^{\prime}$ & $1983: \mathrm{Q} 4$ \\
\hline$h_{0}^{\text {Minimum wage }}$ & $1982: \mathrm{Q} 2$ \\
\hline$h_{0}^{\text {Social Security }}$ & $1983: \mathrm{Q} 1$ \\
\hline$\left[a_{0}, b_{1}\right]$ & $1983: \mathrm{Q} 4$ \\
\hline$\left[c_{1}, c_{5}, c_{9}\right]$ & $1980: \mathrm{Q} 1$ \\
\hline
\end{tabular}




\section{Table 7}

$$
\Delta W_{t}=a_{0}+b(L) U_{t}+c_{1}\left[\sum_{i=1}^{4} \frac{\Delta P_{t-i}}{4}\right]+d_{0}\left[\sum_{i=0}^{3} \frac{\Delta \theta_{t-i}}{4}\right]-g^{\prime}(L) \Delta W_{t-1}+h(L) z_{t}+\epsilon_{t}
$$

\begin{tabular}{|c|c|c|c|}
\hline \multicolumn{4}{|c|}{ Smoothed 1-year Price Inflation and Labor Productivity Series (Price Index: CPI-U) } \\
\hline Parameter & $\begin{array}{l}\text { Andrews/Quandt } \\
\text { Supremum LM Test } \\
\text { (Middle 70\%) }\end{array}$ & $\begin{array}{l}\text { Andrews/Ploberger } \\
\text { Exponential LM Test } \\
\text { (Middle 80\%) }\end{array}$ & $\begin{array}{l}\text { Andrews/Ploberger } \\
\text { Average LM Test } \\
\text { (Middle 80\%) }\end{array}$ \\
\hline Parameter Vector & $\begin{array}{l}21.611^{*} \\
(0.054)\end{array}$ & $\begin{array}{l}8.025^{* *} \\
(0.042)\end{array}$ & $\begin{array}{c}12.359 * * \\
(0.027)\end{array}$ \\
\hline$a_{0}$ & $\begin{array}{c}12.345^{* * * *} \\
(0.008)\end{array}$ & $\begin{array}{c}3.753 * * * \\
(0.004)\end{array}$ & $\begin{array}{c}4.533 * * * \\
(0.008)\end{array}$ \\
\hline$b_{1}$ & $\begin{array}{c}10.910 * * \\
(0.017)\end{array}$ & $\begin{array}{c}3.024^{* *} \\
(0.014)\end{array}$ & $\begin{array}{l}3.687 * * \\
(0.020)\end{array}$ \\
\hline$c_{1}$ & $\begin{array}{c}13.153 * * * \\
(0.006)\end{array}$ & $\begin{array}{c}4.044 * * * \\
(0.002)\end{array}$ & $\begin{array}{c}4.696 * * * \\
(0.007)\end{array}$ \\
\hline$d_{0}$ & $\begin{array}{c}2.941 \\
(0.566)\end{array}$ & $\begin{array}{c}0.333 \\
(0.633)\end{array}$ & $\begin{array}{c}0.512 \\
(0.661)\end{array}$ \\
\hline$g_{2}^{\prime}$ & $\begin{array}{c}9.247^{* *} \\
(0.037)\end{array}$ & $\begin{array}{c}2.458^{* * *} \\
(0.029)\end{array}$ & $\begin{array}{c}3.105^{* *} \\
(0.035)\end{array}$ \\
\hline$h_{0}^{\text {Minimum wage }}$ & $\begin{array}{c}2.255 \\
(0.722)\end{array}$ & $\begin{array}{c}0.406 \\
(0.550)\end{array}$ & $\begin{array}{c}0.712 \\
(0.506)\end{array}$ \\
\hline$h_{0}^{\text {Social Security }}$ & $\begin{array}{c}5.364 \\
(0.211)\end{array}$ & $\begin{array}{c}1.052 \\
(0.188)\end{array}$ & $\begin{array}{c}1.396 \\
(0.212)\end{array}$ \\
\hline$\left[a_{0}, b_{1}\right]$ & $\begin{array}{c}12.375 * * \\
(0.035)\end{array}$ & $\begin{array}{c}3.837^{* * *} \\
(0.026)\end{array}$ & $\begin{array}{l}5.151^{* * *} \\
(0.028)\end{array}$ \\
\hline
\end{tabular}

Note: Values of the test statistic are reported in columns 2-4, with asymptotic $p$-values reported below in parentheses.

* Significant at the 10 percent level ** Significant at the 5 percent level. *** Significant at the 1 percent level 
Table 7 (continued)

\begin{tabular}{|l|l|l|}
\hline \multicolumn{2}{|c|}{ Smoothed 1-year Price Inflation and Labor Productivity Series (Price Index: CPI-U) } \\
\hline Restriction & Value of Test Statistic & p-Value \\
\hline \hline $1+\Sigma g^{\prime}=\Sigma c$ & $\chi^{2}(1)=15.281^{* * *}$ & 0.00 \\
\hline $1+\Sigma g^{\prime}=d_{0}$ & $\chi^{2}(1)=19.253^{* * *}$ & 0.00 \\
\hline $\begin{array}{l}1+\Sigma g^{\prime}=\Sigma c \\
1+\Sigma g^{\prime}=d_{0}\end{array}$ & $\chi^{2}(2)=22.641^{* * *}$ & 0.00 \\
\hline
\end{tabular}

* Significant at the 10 percent level ** Significant at the 5 percent level. *** Significant at the 1 percent level 


\section{FIGURE 2}

Supremum LM Statistic: Truncated Lag Length Model (Level)

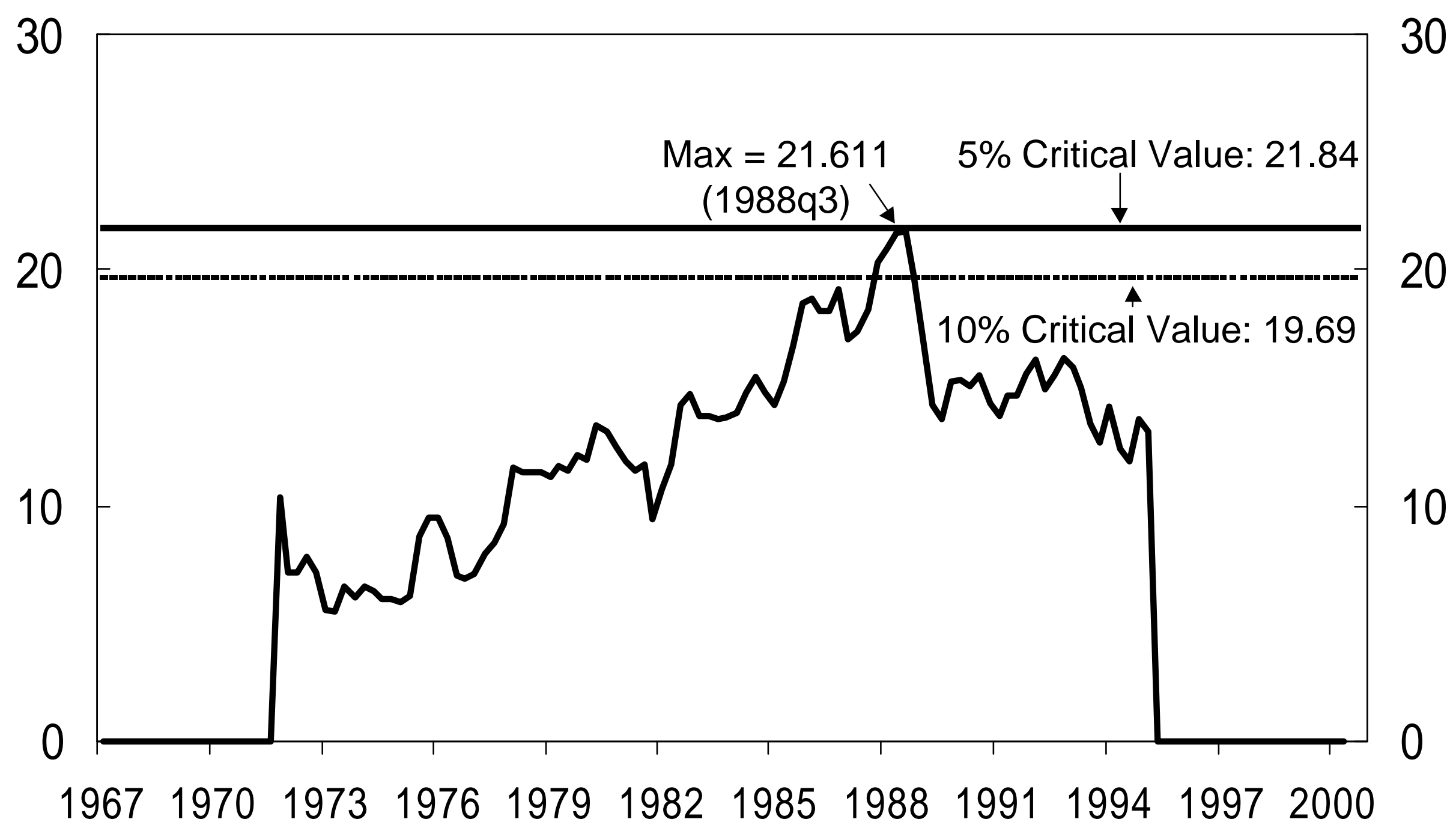




\section{Table 8}

Selected Break Dates Across the Truncated Lag Length Model

\begin{tabular}{|l|l|}
\hline Parameter & \\
\hline \hline Parameter Vector & $1988: \mathrm{Q} 3$ \\
\hline$a_{0}$ & $1987: \mathrm{Q} 4$ \\
\hline$b_{1}$ & $1987: \mathrm{Q} 4$ \\
\hline$c_{1}$ & $1987: \mathrm{Q} 4$ \\
\hline$c_{5}$ & --- \\
\hline$c_{9}$ & --- \\
\hline$d_{0}$ & $1992: \mathrm{Q} 1$ \\
\hline$g_{2}^{\prime}$ & $1988: \mathrm{Q} 3$ \\
\hline$h_{0}^{\text {Minimum wage }}$ & $1971: \mathrm{Q} 4$ \\
\hline$h_{0}^{\text {Social Security }}$ & $1992: \mathrm{Q} 1$ \\
\hline$\left[a_{0}, b_{1}\right]$ & $1987: \mathrm{Q} 4$ \\
\hline$\left[c_{1}, c_{5}, c_{9}\right]$ & --- \\
\hline
\end{tabular}




\section{Table 9}

Estimates of the Natural Rate of Unemployment: Prime-age (25-54) Males

\begin{tabular}{|l|c|c|c|}
\hline \multicolumn{1}{|c|}{ Price Index: } & $\mathrm{U}^{*}$ & $\mathrm{SE}\left(\mathrm{U}^{*}\right)$ & $\begin{array}{c}95 \text { Percent } \\
\text { Confidence Interval }\end{array}$ \\
\hline \hline CPI-U & 3.19 & 0.27 & {$[2.655,3.724]$} \\
\hline PCE Deflator & 3.79 & 0.24 & {$[3.315,4.265]$} \\
\hline Core CPI & 3.10 & 0.29 & {$[2.526,3.674]$} \\
\hline
\end{tabular}




\section{FIGURE 3}

Natural Rate Estimate: Males aged 25 to 54

(Percent)

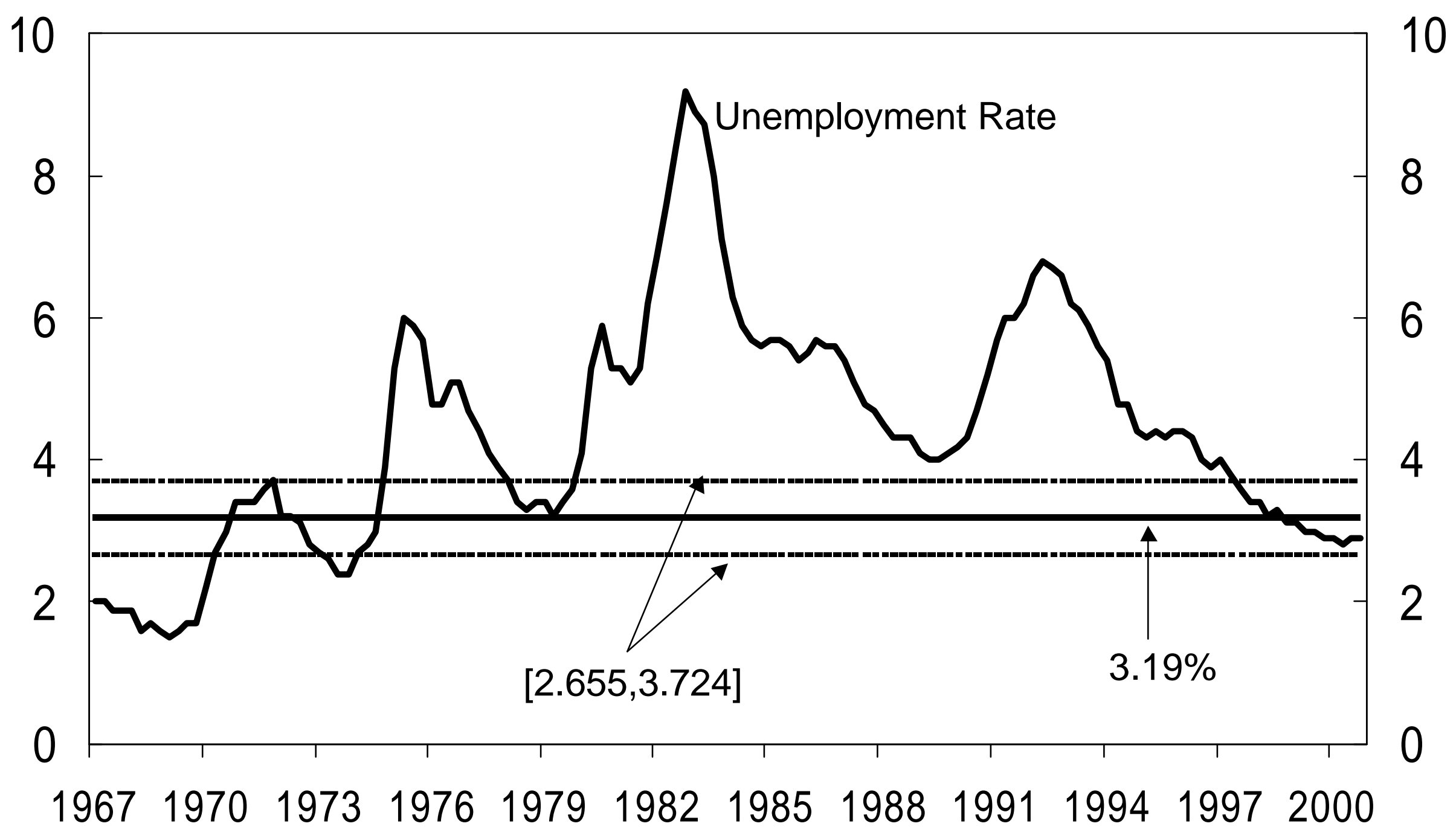




\section{Data Appendix}

Variable Name

LXNFC

LEPRIVA

LSWP

PCU

JCZ

PCUSLFE

LRM25

LXNFA

MINW

SPLICED_WAGE

WAGEINF

WAGEINF2

PI_TOT

PI_PCE

PI_CORE

\section{Description}

Compensation per hour in the Nonfarm Business Sector. SA, 1992=100.

Average Hourly Earnings for Private Nonfarm Payrolls. SA, \$hour.

Employment Cost Index measure of wages for Private Industry workers. SA, June 1989=100.

CPI-U: all items. SA, 1982-84=100.

PCE: Chain-type price index. SA, 1996=100.

CPI-U: all items less food and energy (or "Core CPI”). SA, 1982-84=100.

Civilian Unemployment Rate: Men aged 25-54 years. SA, percent.

Output per Hour of all persons in the Nonfarm Business Sector. SA, 1992=100.

Minimum Hourly Wage Rate in the Nonfarm Sector

This is a combined series in index form. The index is set equal to 100 in 1964:Q1. The period 1964:Q2-1980:Q1 then reflects the growth in compensation per hour (LXNFC). The period from 1980:Q2 onward reflects the growth in the employment cost index measure of wages for private industry workers (LSWP). See Akerlof, Dickens and Perry (2000).

A measure of wage inflation, quarterly at an annual rate.

Calculated as $400 *[\Delta \ln (L X N F C)]$.

An alternate measure of wage inflation, quarterly at an annual rate.

Calculated as: $400 *\left[\Delta \ln \left(S P L I C E D \_W A G E\right)\right]$.

A measure of price inflation, quarterly at an annual rate. Calculated as: $400 *[\Delta \ln (P C U)]$.

An alternate measure of price inflation, quarterly at an annual rate.

Calculated as: $400 *[\Delta \ln (J C Z)]$.

A measure of core price inflation, quarterly at an annual rate.

Calculated as: $400 *[\Delta \ln (P C U S L F E)]$.

\section{Source Agency}

Bureau of Labor Statistics

Bureau of Labor Statistics

Bureau of Labor Statistics

Bureau of Labor Statistics

Bureau of Economic Analysis

Bureau of Labor Statistics

Bureau of Labor Statistics

Bureau of Labor Statistics

Department of Labor

Authors' Calculations

Authors' Calculations

Authors' Calculations

Authors' Calculations

Authors' Calculations

Authors' Calculations 


\begin{tabular}{|c|c|c|}
\hline Variable Name & $\underline{\text { Description }}$ & Source Agency \\
\hline PRODTREND & $\begin{array}{l}\text { A measure of trend labor productivity growth, } \\
\text { quarterly at an annual rate. Calculated as: } \\
(400 / 16) *\left[\ln \left(L X N F A / L X N F A_{-16}\right)\right]\end{array}$ & Authors' Calculations \\
\hline MINWAGE & $\begin{array}{l}\text { A measure of effective minimum wage growth, } \\
\text { quarterly at an annual rate. Calculated as: } \\
400 *\left[\Delta \ln (M I N W)-\Delta \ln \left(\text { LEPRIVA }_{-1}\right)\right]\end{array}$ & Authors' Calculations \\
\hline SOCSEC & $\begin{array}{l}\text { Estimate of the direct effect of changes in } \\
\text { payroll tax rates for Social Security and } \\
\text { Medicare. See Lown and Rich (1997). }\end{array}$ & Staff Estimates \\
\hline NIXON & $\begin{array}{c}\text { Dummy variable: } 1971: \mathrm{Q} 3-1972: \mathrm{Q} 3=0.8 \\
\text { Otherwise }=0\end{array}$ & See Gordon (1982) \\
\hline NIXOFF & $\begin{array}{c}\text { Dummy variable: } 1974: Q 2-1975: Q 1=0.4 \\
\text { 1974:Q3 \& 1974:Q4=1.6 } \\
\text { Otherwise }=0\end{array}$ & See Gordon (1982) \\
\hline
\end{tabular}

Note: Data obtained from Haver Analytics U.S. Economic Statistics (USECON) database: www.haver.com 


\section{References}

Akelof, George A., William T. Dickens, and George L. Perry. 2000. "Near-Rational Wage and Price Setting and the Long-Run Phillips Curve." Brookings Papers on Economic Activity, 1:2000, 1-44.

Andrews, Donald W. K. 1993. "Tests for Parameter Instability and Structural Change With Unknown Change Point.” Econometrica 61 (July):821-56.

Andrews, Donald W. K., and Werner Ploberger. 1994. "Optimal Tests when a Nuissance

Parameter is Present Only Under the Alternative.” Econometrica 62 (November):1383- 1414.

Blanchard, Olivier, and Lawrence F. Katz. 1997. "What We Know and Do Not Know about the Natural Rate of Unemployment." Journal of Economic Perspectives 11(1):51-72.

Blau, Francine D., and Lawrence M. Kahn. 1992. "Race and Gender Pay Differentials." In Research Frontiers in Industrial Relations and Human Resources, edited by David Lewin, Olivia S. Mitchell, and Peter D. Sherer. University of Wisconsin.

Bound, John, and George Johnson. 1992. "Changes in the Structure of Wages in the 1980's: An Evaluation of Alternative Explanations." American Economic Review 82 (June):371-92.

Brayton, Flint, John M. Roberts, and John C. Williams. 1999. "What's Happened to the Phillips Curve?" Finance and Economics Discussion Series, 1999-49, Federal Reserve Board (September).

Budd, John W., and Yongjin Nho. 1997. "Testing for a Structural Change in U.S. Wage Determination.” Industrial Relations, 36 (April):160-77.

Clark, Todd E. 1999. "A Comparison of the CPI and the PCE Price Index." Federal Reserve Bank of Kansas City Economic Review, Third Quarter:15-29.

DiNardo, John, Nicole Fortin, and Thomas Lemieux. 1996. "Labor Market Institutions and the Distribution of Wages, 1973-1992: A Semi-Parametric Approach.” Econometrica 64 (September):1001-44.

Fuhrer, Jeffrey C. 1995. "The Phillips Curve is Alive and Well." Federal Reserve Bank of Boston New England Review, March/April:41-56.

Gomme, Paul. 1998. "What Labor Market Theory Tells Us about the 'New Economy'." Federal Reserve Bank of Cleveland Economic Review, Third Quarter:16-24.

Gordon, Robert J. 1982. "Inflation, Flexible Exchange Rates, and the Natural Rate of Unemployment." In Workers, Jobs, and Inflation, edited by Martin N. Baily. Brookings. 
. 1985. "Understanding Inflation in the 1980s." Brookings Papers on Economic Activity, 1:1985, 263-99.

. 1988. "The Role of Wages in the Inflation Process." American Economic Review 78 (May):276-83.

. 1990. "U.S. Inflation, Labor's Share, and the Natural Rate of Unemployment." In Economics of Wage Determination, edited by Heinz König. Springer Verlag.

. 1997. "The Time-Varying NAIRU and Its Implications for Economic Policy." Journal of Economic Perspectives 11(1):11-32.

1998. "Foundations of the Goldilocks Economy: Supply Shocks and the Time-Varying NAIRU." Brookings Papers on Economic Activity, 2:1998, 297-346.

Hansen, Bruce E. 1992. "Testing for Parameter Stability in Linear Regression Models.” Journal of Policy Modeling 14 (August):517-33.

. 1997. “Approximate Asymptotic $P$ Values for Structural-Change Tests.” Journal of Business and Economic Statistics 15 (January):60-7.

Katz, Lawrence F., and Alan B. Krueger. 1999. “The High-Pressure U.S. Labor Market of the 1990s. Brookings Papers on Economic Activity, 1:1999, 1-65.

Lebow, David, Louise Sheiner, Larry Slifman, and Martha Starr-McCluer. 1999. "Recent Trends in Compensation Practices." Finance and Economics Discussion Series, 1999-32, Federal Reserve Board (July).

Lown, Cara S., and Robert W. Rich. 1997. "Is There an Inflation Puzzle?” Federal Reserve Bank of New York Economic Policy Review, December:51-69.

Mitchell, Daniel J.B. 1985. "Shifting Norms in Wage Determination." Brookings Papers on Economic Activity, 2:1985, 575-99.

. 1987. "Wage Trends and Wage Concessions: Implications for Medium-Term Economic Expansion.” Economic Outlook for 1987, 266-335.

. 1994. “A Decade of Concession Bargaining." In Labor Economics and Industrial

Relations: Markets and Institutions, edited by Clark Kerr and Paul D. Staudohar. Harvard University Press.

Murphy, Kevin M., and Finis Welch. 1992. "The Structure of Wages.” Quarterly Journal of Economics 107 (February):285-326. 
Neumark, David. 1993. "Declining Union Strength and Labor Cost Inflation in the 1980s." Industrial Relations 32 (Spring):204-22.

Neumark, David, and Jonathan S. Leonard. 1993. "Inflation Expectations and the Structural Shift in Aggregate Labor-Cost Determination in the 1980s." Journal of Money, Credit, and Banking 25 (November):786-800.

Newey, Whitney K., and Kenneth D. West. 1987. "A Simple, Positive Semi-Definite, Heteroskedasticity Consistent Covariance Matrix.” Econometrica 55 (May):703-8.

Phillips, A. W. 1958. "The Relation Between Unemployment and the Rate of Change of Money Wage Rates in the United Kingdom, 1861-1957.” Economica 25(November):283-99.

Rich, Robert W., and Donald Rissmiller. 2000. "Understanding the Recent Behavior of U.S. Inflation.” Federal Reserve Bank of New York Current Issues in Economics and Finance, (July).

Staiger, Douglas, James H. Stock, and Mark W. Watson. 1997. "How Precise Are Estimates of the Natural Rate of Unemployment?" In Reducing Inflation: Motivation and Strategy, edited by Christina D. Romer and David H. Romer. University of Chicago Press.

Tootell, Geoffrey M.B. 1994. "Restructuring, the NAIRU, and the Phillips Curve." Federal Reserve Bank of Boston New England Review, March/April:31-44.

Tulip, Peter. 2000. “Do Minimum Wages Raise the NAIRU?" Finance and Economics Discussion Series, 2000-38, Federal Reserve Board (August).

Vroman, Wayne, and John M. Abowd. 1988. "Disaggregated Wage Developments" Brookings Papers on Economic Activity, 1:1988, 313-38. 